\title{
NOTA DE APRESENTAÇÃO ÀS TRADUÇÕES
}

Cinquenta anos separam a publicação dos dois textos de Gilles Deleuze cujas traduções lançamos nesta edição da revista Limiar. "Descrição da mulher”, escrito em 1945 , aos 20 anos, no ímpeto da leitura de $O$ ser e o nada, de Jean-Paul Sartre, de 1943, e "Imanência: uma vida", escrito às vésperas de sua morte, em 1995, que inicia com a pergunta "O que é um campo transcendental?" e a responde com uma impressionante síntese de seu pensamento, sem deixar de indicar para o leitor algumas de suas principais referências no processo de construção do conceito de imanência, como: Matéria e memória (H. Bergson), A transcendência do ego (J-P. Sartre) e Doutrina da Ciência (J.G. Fichte). De um lado, um estilo experimental que flerta com a ontologia fenomenológica, mas já buscando ali provocar e percorrer algumas fissuras, tomando como ponto de partida a afirmação de que o mundo que se descortina em Sartre é "um mundo assexuado" onde a mulher não tem um estatuto filosófico. Do outro lado, um estilo conciso, elegante, preciso, "pura potência", que faz de si mesmo um acontecimento capaz de expressar-se como a singularidade de uma vida justamente naquilo que ela não tem de individual, nem de subjetivo. Em comum, a frequente presença, implícita ou explicitamente, do texto literário na composição da trama conceitual. "Descrição da mulher" foi expressamente renegado por Deleuze, e cada leitor poderá encontrar uma ou várias boas razões para isso. Foi autorizado pela família e pelos editores para ser publicado na França apenas recentemente, incluído na coletânea editada por David Lapoujade: Gilles Deleuze, lettres et autres textes (Minuit, 2015), sob alegação de que não era possível conter as aparições piratas, na França, vindas do estrangeiro, muitas vezes contendo erros... A tradução que ora se apresenta foi feita a partir do texto original da revista Poésie 45 ( $\mathrm{n}^{\mathrm{o}}$ 28, oct-nov. 1945), numa cópia gentilmente cedida pelo prof. Luiz B. L. Orlandi. "Imanência: uma vida" foi originalmente publicado na abertura do número 47 da revista Philosophie (Minuit), integralmente dedicado a Deleuze, em setembro de 1995, apenas algumas semanas antes de seu falecimento.

Sandro Kobol Fornazari 